\title{
Adaptation Trial and Growth Performance of Multipurpose Trees/Shrubs Species at Meti Site of Kellem Wollega Zone, Oromia, Ethiopia
}

\author{
Temam Mama \\ Haro Sabu Agricultural Research Center, Oromia, Ethiopia
}

\begin{abstract}
The research is financed by Oromia Agricultural Research institute
Abstract

This study was conducted at Meti Site of Haro Sabu Agricultural research center, Oromia. The objective of this study was to evaluate the adaptability and growth performance of different multipurpose trees/shrubs species and select or screen those best performed and adapted to the area. For this seedling of: Acacia senegal, Pinus patula, Callistemon citrinus, Olea africana and Spathodea nilotica were out planted on a plot of $14 \mathrm{~m} * 14 \mathrm{~m}$. The space between block of each species was $3 \mathrm{~m}$ and Spacing between rows and within row was based on the recommendations of each species. In order to fit the given objectives growth parameter data of trees/shrubs (height, root collar diameter (only for trees $<1.3 \mathrm{~m}$ in height), diameter at breast height (for trees $\geq 1.3 \mathrm{~m} \mathrm{height)}$ and survival rate) were collected by an interval of 6 months and Analyses of variance and LSD tests were employed to assess the results at $\mathrm{p}=0.05$ using Minitab 17. As a result, the higher mean height growth was observed on Callistemon citrinus (2.59 m), Spathoda nilotica (2.48 m) and Pinus patula (2.34 m). Again Gains in root collar diameter (RCD) was significantly highest on Pinus patula $(37.75 \mathrm{~cm}, 2.81 \mathrm{~cm})$ and Spathodea nilotica $(32.08 \mathrm{~cm}, 3.52 \mathrm{~cm})$. The Mean survivals of all trees grown at site were good ranging from $85.36 \%$ ( Pinus patula) to $100 \%$ (Spathodea nilotica (100\%). Generally this finding may help forest managers (stakeholder) to allocate species into the site that grow and adapt well. To select the most adaptable ones for such areas, use them at wider scale and increase their importance in the overall agricultural productivity (soil conservation, timber production, shading purpose, etc) and in general multifunction purposes in the area, further testing of provenances of the best performing species is recommended.
\end{abstract}

Keywords: Growth performance, Meti, Relative growth rate in height (RGRH), Root collar diameter (RCD), Survival percentage.

DOI: $10.7176 / \mathrm{JEES} / 11-11-03$

Publication date: November $30^{\text {th }} 2021$

\section{Background and Justification}

Western Ethiopia, specifically western Oromia is well known by vegetation cover and most of the surrounding area is covered by forests comprised of a rich mixture of woody species (Yadessa et al., 2000). In spite of the importance of forest ecosystem to the livelihoods of the people in the area, the forest is dwindling from time to time due to high exploitation of woody and non-woody products. Rapid deforestation caused by an escalating demand for fuel wood expansion for agriculture has brought an ever-increasing pressure on native woodland species (Mihretu et al, 2004). If no remedial action is taken, this will cause severe impact on agricultural productivity leading to energy poverty and environmental degradation. Frequent and severe droughts often present a serious threat for millions of lives (Brockerhoff et al., 2008), which have occurred once in a decade in the 1970s and 1980s. A shortage of biomass energy is also one of unsustainable use of natural resources. Currently, biomass energy constitutes $88.7 \%$ of all energy consumed in Ethiopia which is mainly derived from the woody biomass resources (forests, woodlands, shrub lands, planted trees, agro forests). Agro forestry system has much potential for supplying poles, farm equipment, and fuel wood and agricultural improvements (Yadessa et al., 2000).

Multipurpose tree and shrubs species (MPTS) play a considerable role in addressing such multifaceted demands in the mixed agricultural production system (Alemu et al., 2000). They have the ability to fit into the farming system to be used as a source of manure, mulch, soil conservation, forage, fuel wood, farm implements and other like shade and shelter (Berhe et al., 2001). Before developing new trees and shrub species for any type of agro forestry and forestry activities in the area, evaluation of compatible species is very critical. Deciding what species to plant in any agroforestry system to meet the intended objectives require a well- conducted field trial to match a species to a particular site (Zobel et al, 1984 and J. Evans, 1986). The first trial should be a species screening trial that will test the survival and early growth of the species in one to three years (Eldridge $e t$ al., 1994). In Seyo district where Meti site was found, some stake holders: bureau of environmental protection, responsible NGOS (Sustainable land management project and Ethiopian Evangelical Church Mekane Yesus) and other related professionals in collaboration with the local people have been planting different trees in areas without testing their survivals and early growth performance. However, despite various efforts that have been 
made by the different actors in the area, still there is a large gap between demand and supply of forest, agricultural commodities and other basic necessities in the area which are imposing more pressure on the existing forest land through encroachment, overgrazing and unplanned legal and illegal felling. So this activity was intended to cope up with such challenges to develop tree species for agro forestry and forestry activities through adaptation of different tree species to the area as best alternative option.

\section{MATERIAL AND METHODS}

\subsection{Description of the Study Site}

The study was conducted at Meti sub site of Haro-Sabu Agricultural Research Center which is located in Ifa Galano peasant association of Seyo district, Kellem Wollega Zone; Oromia National Regional State(Figure1). It is found at $647 \mathrm{~km}$ away from Finfinne and $5 \mathrm{~km}$ from the nearby towns DembiDollo. The elevation of the area is 1300-2000m.a.s.1, temperature $23-34^{\circ} \mathrm{c}$, rainfall $1000-1300 \mathrm{~mm}$ which has a beautiful scene for vision and is quite conducive for agricultural production system under rain-fed in the present climatic conditions.

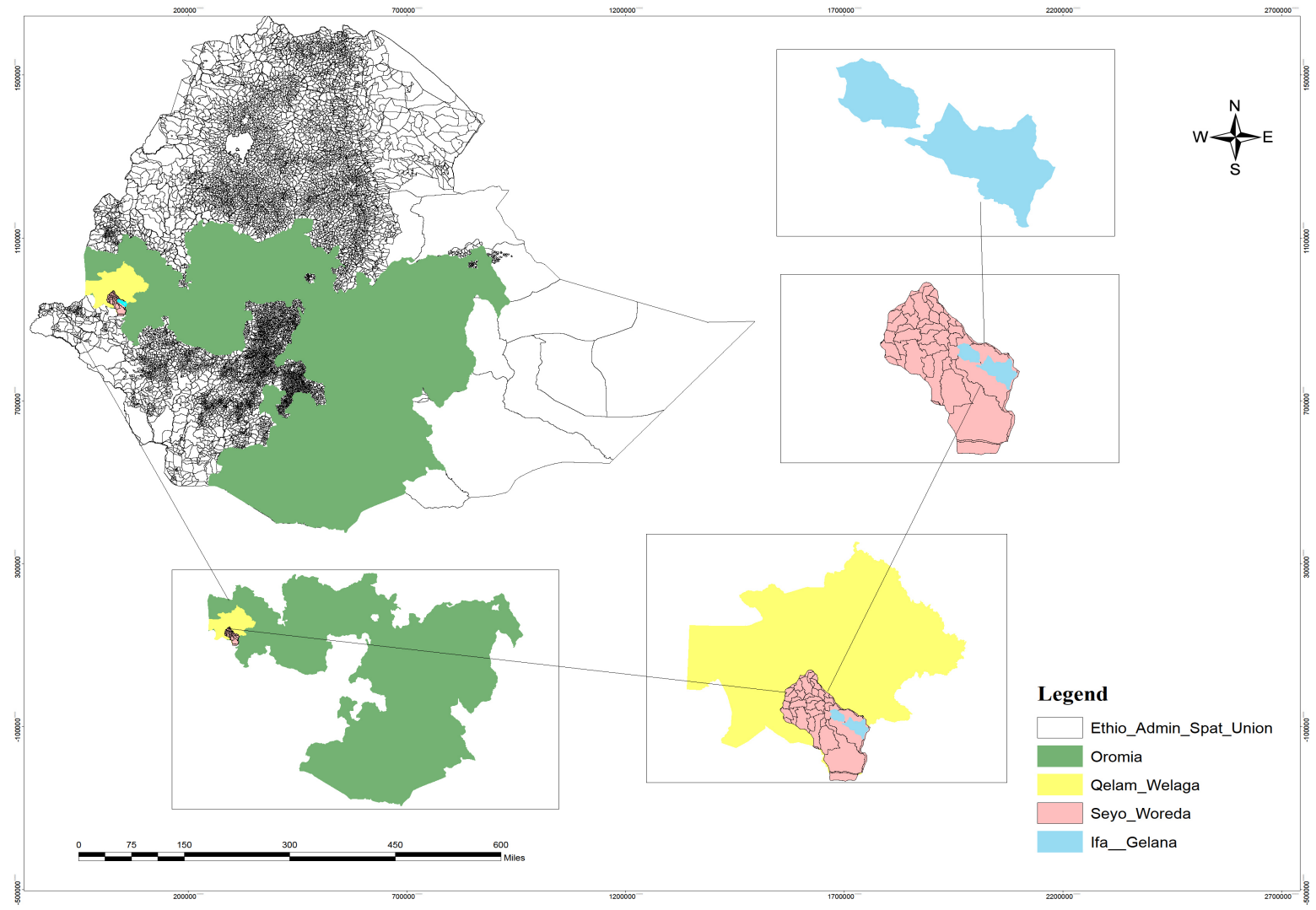

Figure 1.Map of the study area.

\subsection{Experimental design}

Seedlings of each tree/shrubs species: Acacia senegal, Pinus patula, Callistemon citrinus, Olea africana and Spathodea nilotica were out planted on a plot of $14 \mathrm{~m} * 14 \mathrm{~m}$. The space between block of each species was $3 \mathrm{~m}$ and between row and within row were $3 \mathrm{~m} \times 3 \mathrm{~m}$ for (Acacia senegal), $2 \mathrm{mx} 2 \mathrm{~m}$ (Pinus patula), $1.5 \mathrm{mx} 1.5 \mathrm{~m}$ (Callistemon citrinus), $2.5 \mathrm{mx} 2.5 \mathrm{~m}$ (Spathodea nilotica) and $2 \mathrm{~m} \times 2 \mathrm{~m}$ (Olea africana). To take growth parameter of trees/shrubs, the tag was given to seedlings with its corresponding numerical code and Growth parameter of trees/shrubs (height, root collar diameter, diameter at breast height and survival rate) was collected from each tree within plots except the border. RCD were collected only up to the tree reaches 1.3 meters in height whereas height and survivals were up to the end of the period of the activity.

\subsubsection{Plant Material and Nursery Management}

Seeds of the multipurpose trees/shrubs species planted at the site were obtained from National Forest Research Center (NFRC). Seedlings were raised at nursery site of an area (Meti nursery site). Seeds of the trees/shrubs species were sown on seedbeds and after germination pricked out into white polythene tubes. Seedlings were watered twice per day during the morning and evening except on days when it rained. Weeds were removed on detection and root pruning was done when ever roots out grew the polythene containers as well as hardening off seedlings were under taken before planting/transplanting to the site. 


\subsubsection{Other activities}

Hoeing of seedlings using hoes and mowing grass and weeds using sickles was carried out to facilitate seedlings growth.

\subsection{Data collection}

Growth parameters of trees/shrubs (height, root collar diameter, diameter at breast height and survival rate) were collected per six months from each tree within plots except the border since establishment of activity. RCD were collected only up to the tree reaches 1.3 meters in height and after diameter at breast height was measured. However height and survivals of trees were taken up to the end of the period of the activity.

\subsection{Statistical analysis}

Data on survival, height and root collar diameter were separately subjected to ANOVA to determine differences among tree species in their growth. Least significant test was employed for Multiple Comparisons when significant differences were found between the growths of the species $(p=0.05)$. The statistical procedures were carried out by Minitab 17 software package.

\section{RESULT AND DISCUSSION}

\subsection{Growth parameter of Tree Species}

\section{Survival}

Mean survivals percentage of tree species planted at the area was significantly higher on Spathoda nilotica (100\%), Olea africana (98.41\%), Acacia senegal (98.26\%), and Callistemon citrinus (96.75\%), while the lower was observed on Pinus patula (85.36\%) (Figure1). Although the lower mean survival percentage was observed on Pinus patula, the range of survival percentage of trees $(85.36 \%-(100 \%)$ at the area was good indication to use them at wider scale and increase their importance in the overall agricultural productivity (soil conservation, timber production, shading purpose, etc) in general multifunction purposes in the area.

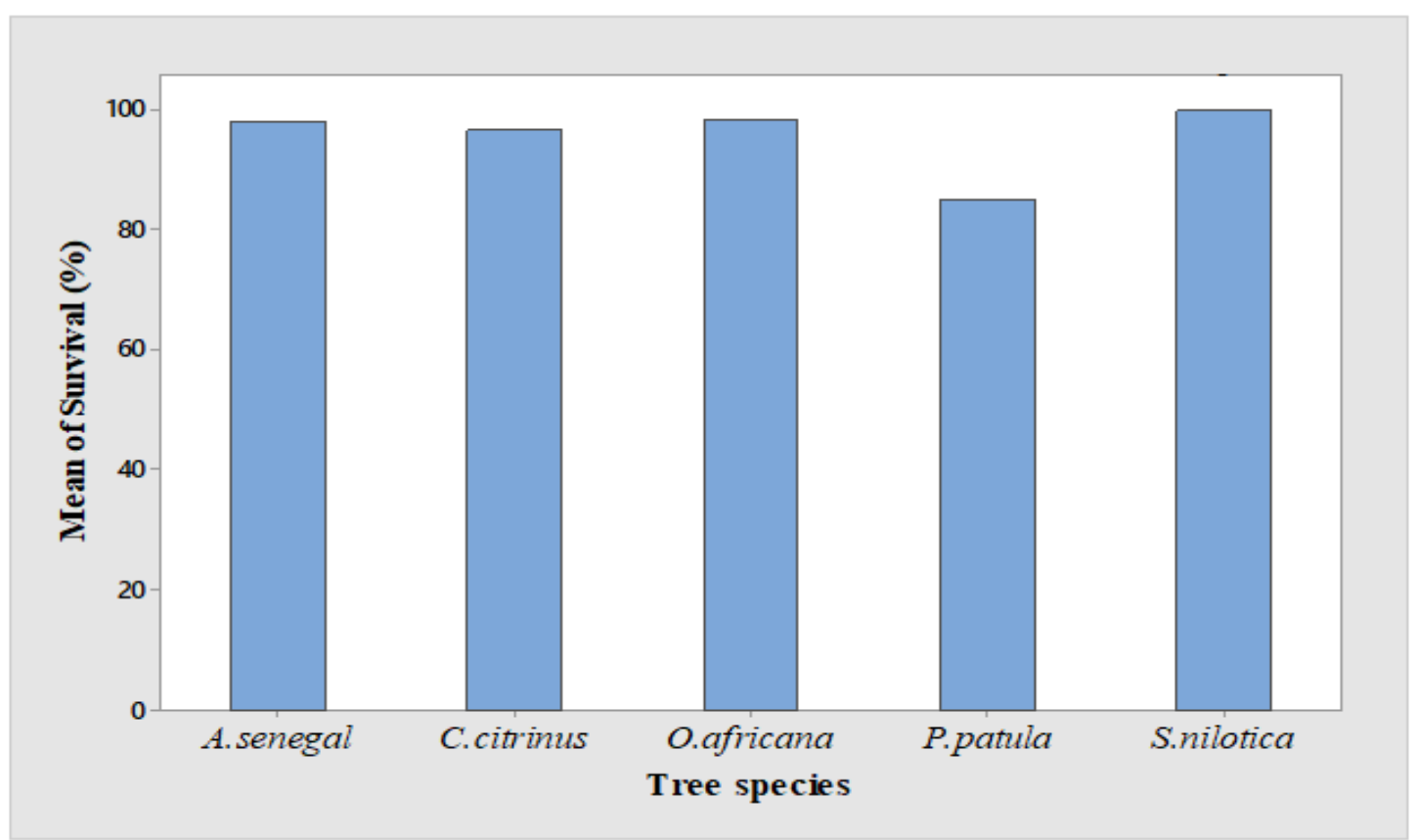

Figure 2.Mean survival percentage of the tree/shrubs species observed at study site.

\subsubsection{Height and diameter growth}

Analysis of variance of the height and diameter at breast height (DBH) of the tree species was significantly different $(\mathrm{p}<0.05)$ at study site $($ Table2). Accordingly mean height of tree species was significantly higher on Callistemon citrinus $(2.59 \mathrm{~m})$, Spathodea nilotica $(2.48 \mathrm{~m})$ and Pinus patula $(2.34 \mathrm{~m})$, Olea africana $(1.64 \mathrm{~m})$ was ranked $2^{\text {nd }}$ and the lower was observed on Acacia Senegal $(0.44 \mathrm{~m})$. Again the mean diameter at breast height (DBH) of tree species was significantly higher on Spathoda nilotica $(4.29 \mathrm{~cm})$ and Pinus patula $(3.74 \mathrm{~cm})$, followed by Callistemon citrinus $(1.67 \mathrm{~cm})$, Acacia senegal $(1.03 \mathrm{~cm})$ and Olea africana $(0.85 \mathrm{~cm})$. The overall basal area of tree species was also higher on Spathodea nilotica $\left(0.001965 \mathrm{~m}^{2}\right)$ followed by Pinus patula $\left(0.001380 \mathrm{~m}^{2}\right)$ and the lowest was observed on Callistemon citrinus $\left(0.000286 \mathrm{~m}^{2}\right)$, Acacia senegal $\left(0.000147 \mathrm{~m}^{2}\right)$ and Olea africana $\left(0.000089 \mathrm{~m}^{2}\right)$.

These results of mean height growth of the tree species planted at the site were good in relation to those 
reported by (Azene, Birnie, and Tengnas 1993) and Forestry Research center (unpublished report). As tall trees usually being better adapted to the site than short trees; fast growth of seedlings is an important indicator in terms of determining the situation of growth response especially in the first growing period (Baris and Ertenkin, 2010), higher height growth observed on Callistemon citrinus, Spathodea nilotica and Pinus patula than Olea africana and Acacia Senegal may seen as a measure of the adaptability of trees to the environment .Again the better height growth of Olea africana and Acacia Senegal than some reported by ((Azene, Birnie, and Tengnas 1993, Forestry Research center, 1986 ) are good indication to use them at area.

Table1.Overall Mean height, Diameter at Breast Height (DBH) and basal area of different trees/shrubs species at Meti site

\begin{tabular}{llll}
\hline Tree species & Mean height $(\mathrm{m})$ & Mean $\mathrm{DBH}(\mathrm{cm})$ & Mean BA $\left(\mathrm{m}^{2}\right)$ \\
\hline Acacia senegal & $0.44 \pm 0.1287^{\mathrm{c}}$ & $1.03 \pm 0.924^{\mathrm{bc}}$ & $0.000147 \pm 0.000399^{\mathrm{c}}$ \\
Callistemon citrinus & $2.59 \pm 1.0318^{\mathrm{a}}$ & $1.67 \pm 0.934^{\mathrm{b}}$ & $0.000286 \pm 0.000280^{\mathrm{c}}$ \\
Spathodea nilotica & $2.48 \pm 1.4745^{\mathrm{a}}$ & $4.29 \pm 2.579^{\mathrm{a}}$ & $0.001965 \pm 0.002149^{\mathrm{a}}$ \\
Olea africana & $1.64 \pm 0.7746^{\mathrm{b}}$ & $0.85 \pm 0.647^{\mathrm{c}}$ & $0.000089 \pm 0.000128^{\mathrm{c}}$ \\
Pinus patula & $2.34 \pm 1.724^{\mathrm{a}}$ & $3.74 \pm 1.916^{\mathrm{a}}$ & $0.001380 \pm 0.001730^{\mathrm{b}}$ \\
\hline
\end{tabular}

Mean values followed by the same letters within each column are not significantly different at $\mathrm{P}<0.05$ level according to least Significant Difference (LSD) test. Values are expressed as mean \pm standard error. $\mathrm{DBH}=$ Diameter at Breast Height, BA=Basal Area.

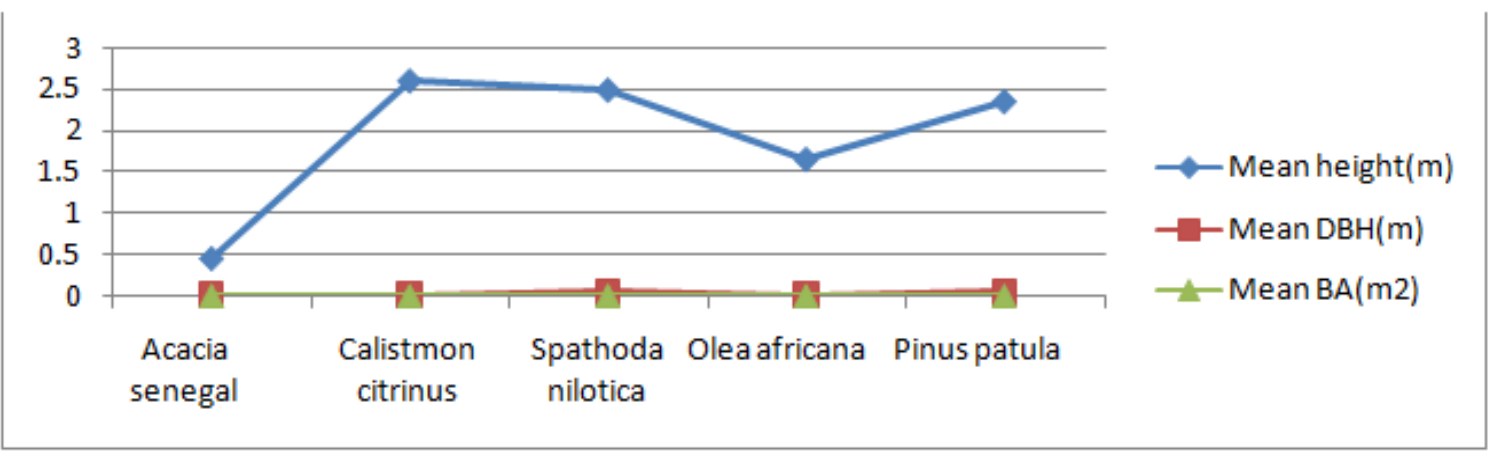

Figure 3.Growth of mean height (m), Basal Area (m2), mean DBH (m) for Acacia senegal, Callistemon citrinus, Spathodea nilotica, Olea africana and Pinus patula trees/shrubs species.

\subsubsection{Root Collar Diameter (RCD)}

The root collar diameter data revealed that there were highly significant $(\mathrm{p}<0.001)$ differences among the species at the site. High mean value of root collar diameter was observed on Spathodea nilotica $(3.52 \mathrm{~cm})$ and Pinus patula $(2.81 \mathrm{~cm})$ while it was low in Olea africana $(1.31 \mathrm{~cm})$, Callistemon citrinus $(1.24 \mathrm{~cm})$ and Acacia senegal $(0.85 \mathrm{~cm})$ (Figure 3$)$. These results of root collar diameter growth may augment the growth performance of trees at the site.

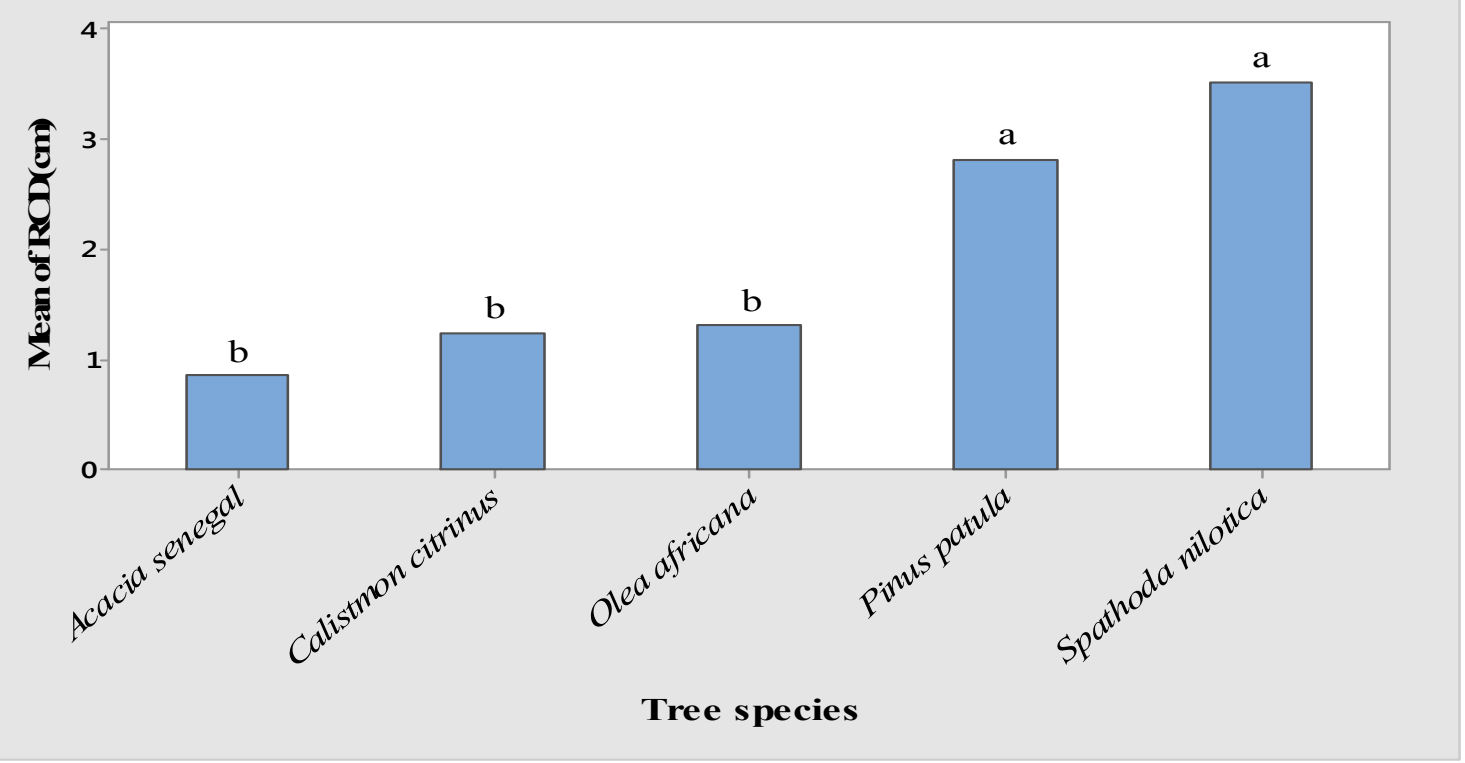

Figure 4.Overall mean Root Collar diameter (RCD) of the five young trees/shrubs species at Meti site. 


\section{Conclusions and Recommendations}

The results of the present study indicate that trees/shrubs species survival was higher on Spathoda nilotica (100\%), Olea africana (98.41\%), Acacia senegal (98.26\%), and Callistemon citrinus (96.75\%), while mean survival of Pinus patula was lower (85.36\%). Again the mean height growth of Callistemon citrinus $(2.59 \mathrm{~m})$, Spathoda nilotica $(2.48 \mathrm{~m})$ and Pinus patula $(2.34 \mathrm{~m})$ were significantly $(\mathrm{p}<0.05)$ higher than Olea africana and Acacia senegal. Again overall gains in root collar diameter (RCD) of the tree species were significantly higher on Spathoda nilotica $(3.52 \mathrm{~cm})$ and Pinus patula $(2.81 \mathrm{~cm})$. However these results of survival, height and diameter growth of tree species were seems good in relation to some reported on other area. Therefore this work concludes that, these results on growth response of tree species at this site may help forest managers (stakeholder) to allocate species into the site that grow and adapt well. To select the most adaptable ones for such areas, use them at wider scale and increase their importance in the overall agricultural productivity (soil conservation, timber production, shading purpose, etc) and in general multifunction purposes in the area, further testing of provenances of the best performing species is recommended.

\section{References}

Alemu B, Mamo T, Zewdie A, Ahmed E (2000) Promising multipurpose tree species and their response to land form on highland vertisols at Chefe Donsa, central highland of Ethiopia. pp. 145-155.5.

Azene Bekele Birnie, A and Tengances B, (1993).Useful Trees and Shrubs for Ethiopia.SIDA's Regional Soil Conservation Unit, Kenya, pp.356, 412

Bayley, A. 1995a.The effects of seedling age, seedling quality, and post planting field conditions on survival of Pinus patula seedlings produced fewer than two nursery growing regimes. Sappi Forests Report PP10/95. Sappi Forests Research, Howick.

Berhe K, Conchedda G, Jabbar M (2001) Areas suitable for five leguminous trees and shrubs in Ethiopia: A digital data based analysis. Ethiopian Journal of Natural Resources (EJNR) 3(1): 77-97.6.

Brockerhoff EG, Jactel H, Parrotta JA, Quine CP, Sayer JJ (2008) Plantation forests and biodiversity: oxymoron or opportunity? Biodiversity Conservation 17: 925-951.4.

B. Zobel and Jalbert J. Applied Forestry Improvement. John Wiley and Sons, New York, 1984, pp. 505.

Evans, G. (1972). Quantitive Analysis of Plant Growth, Berrkeley, University of California, pp.632

Ferias et al (Eds.). Recommended research results for improving crop, livestock and natural resources productivity in western Oromia; users' manual. Oromia Agricultural Research Institute, Bako Agricultural research center, Oromia, Ethiopia.

Forestry Research center, Research note No.2 (1986) on Growth of some forest trees in Ethiopia and suggestion for species selection in different climatic Zones, Addis Ababa.

J. Evans. Plantation Forestry in the tropics. Oxford University Press, New York, 1986.

K. Eldridge, J. Davidson, C. Harwood and G. van Wyk.Eucalyptus Domestication and Breeding Clarendon Press. Oxford, 1994, pp. 288.

Mihretu M, Gezahegn A, Belachew (2004). Early survival and height performance of some Australian species in field trials at Didessa

Pancel, L.1993. Forestation, pp.646-722.in; 1.pancel (ed.), Tropical Forestry hand book, Vol., springer-verlag, Berlin, Germany

Rocheleau, D., Weber, S.and Field Jumna, A.1988 Agro forestry in dry land Africa .ICRAF, Nairobi.

Rolando, C. and Allan, R. 2004. Survival and growth of P. patula at two years in response to harvest residue and pest management, Southern African Forestry Journal 200: 17-24.

Yadessa A, Bekere D, Bekele T (2000) Growth performance of different multipurpose tree and shrubs species at Bako, Western Oromia. In: Proceedings of the Fifth Conference of the Ethiopian Society of Soil Science. Addis Ababa, Ethiopia, 30-31 March 2000, Ethiopian Society of Soil Science. Addis Ababa, Ethiopia, pp. $177-186.2$

Yakob G, Asfaw Z, Zewdie S (2014) Wood production and management of woody species in home gardens agroforestry: The case of small holder farmers in Gimbo district, South West Ethiopia. International Journal of Natural Sciences Research 2(10): 165-175.

Young A. 1997.Agroforestry for soil conservation. CAB International, Wallingford, UK. 